\title{
Rice price volatility: a dilemma for public policies in Asia and Europe?
}

\author{
M. Bruna Zolin, Bernadette Andreosso-O'Callaghan \\ Università Ca' Foscari Venezia, Università di Limerick
}

First Draft: 10.08.2010

\begin{abstract}
In 2008 the world's attention was focused on the global food crisis and, as consequence, on the global food security. By mid-2009, commodity prices have dropped sensitively, nevertheless most of them still remain at or above past trend levels.

Fluctuations in prices are not rare in agricultural markets where volatility is a common characteristic.

Among cereals rice has a strategic importance. It is source of nutrition for more than a half of the world population and of income for about two million of farmers. Even if it is produced and consumed everywhere, production and consumption are concentrated in Asia.

Because of its strategic importance, rice is and has been subject to a host of policy interventions that have made it feature among the most distorted of all agricultural commodities.

Export policies have typically been applied by net exporting countries and one of the most commonly applied policy measures, adopted by net importing countries, is the removal or reduction of import duties and taxes on food commodities.

Various forms of producer support measures were introduced, including input subsidies, output price support and an easing of cropland set-aside requirements.

Policies to support consumers and vulnerable groups have included: direct consumer subsidies, tax reductions, distribution from public stocks, price subsidies, public-sector salary increases and social safety net programmes. Selftargeting food-for-work programmes have been put in place by some countries.

Although the EU rice trade represents only 0.4 per cent of world trade a common organisation market (COM) for rice was set-up. It is a complex system aiming at maintaining European rice production destined for domestic and external markets.

This paper aims to expand the above statements. The objective is to review and compare the policies adopted in Asia and in the EU and assess their impact form the point of sustainability (in a broad sense) with the ultimate aim to advance some interpretations and suggestions in the short and long run, having in mind the variables that affect the supply, the demand and the trade.

As a background, the paper first outlines the characteristics of the rice market. Through a regression analysis that could help to understand how the rice price changes. It also considers the policies adopted in Asia and in the EU, highlighting their results on prices from an economic and social point of view. This paper concludes with a number of issues to be borne in mind when interpreting the volatility or rice prices (according to the regression analysis results) the expected policy impact and distortions, and, finally, the "relatively" new strategy: move from food security to selfsufficient food security, one of the long terms goals of the Treaty of Rome (to secure availability of supplies).
\end{abstract}

Keywords food security, rice market, public policies, regression analysis

JEL Codes Q1, F4, H2

Address for correspondence:

Maria Bruna Zolin

Department of Economics

Ca’ Foscari University of Venice

Cannaregio 873, Fondamenta S.Giobbe

30121 Venezia - Italy

Phone: (++39) 0412349132

Fax: (++39) 0412349176

e-mail: zolin@unive.it

This Working Paper is published under the auspices of the Department of Economics of the Ca' Foscari University of Venice. Opinions expressed herein are those of the authors and not those of the Department. The Working Paper series is designed to divulge preliminary or incomplete work, circulated to favour discussion and comments. Citation of this paper should consider its provisional character.

The Working Paper Series is availble only on line (www.dse.unive.it/pubblicazioni) For editorial correspondence, please contact: wp.dse@unive.it
Department of Economic

Ca' Foscari University of Venice

Cannaregio 873, Fondamenta San Giobbe

30121 Venice Italy

Fax: ++39 0412349210 


\section{Introduction}

In 2008, the world's attention was focused on the global food crisis and, as a consequence, on global food security. By mid-2009, commodity prices had dropped substantially; nevertheless, most of these prices still remain at or above past trend levels. Price fluctuations are not rare in agricultural markets where volatility is a common characteristic. The current situation differs however from past experience, given the conjunction of high and/or low prices in all major food and feed commodities. The lessons learnt are that agricultural products are strongly linked one with another and that they are affected by other markets.

Among all cereals, rice holds a strategic importance. It is a source of nutrition for more than half of the world population and it is a major source of income for about two million farmers. Even if it is produced and consumed everywhere, production and consumption are concentrated in Asia (accounting for almost 90 per cent of global production and consumption, with 96 per cent in developing countries). Rice trade is marginal, when compared with other cereals such as wheat and maize. The direction of the small volume of international rice trade is well-established and it is influenced by consolidated ancient traditions. Because of its strategic importance, the rice market is and has been subject to a host of policy measures that have made it feature among the most distorted of all agricultural markets. These measures can be classified into four broad categories: trade, production, consumption and stock policies. Most of these policy measures have however been implemented for limited periods. Export policies have typically been applied by net exporting countries to enhance supply on the domestic market. One of the most commonly applied policy measure is the removal or reduction of import duties and taxes on food commodities. Various forms of producer support measures were introduced, including input subsidies, output price support and an easing of cropland set-aside requirements. Policies to support consumers and 
vulnerable groups have included: direct consumer subsidies, tax reductions, distribution from public stocks, price subsidies, public-sector salary increases and social safety net programmes. Self-targeting food-for-work programmes have also been put in place by some countries. Finally, building and releasing public stocks in order to stabilize domestic food prices have been common measures implemented to contain the problem of rising food prices. Although EU rice trade represents only a very small percentage of the world total rice trade, a common organisation market (COM) for rice was set-up. It is a complex system aiming at maintaining European rice production destined for domestic and external markets.

Set in the framework of these broad challenges, this paper aims to review and compare the policies adopted in Asia and in the EU and to assess their impact from the stand-point of sustainability (in a broad sense). The ultimate aim of this paper is to proffer some interpretations and suggestions in the short and long run, bearing in mind the variables that affect supply, demand and trade.

As a background, the paper first outlines the characteristics of the rice market ${ }^{1}$. It also considers the policies adopted in Asia and in the EU, highlighting their results on prices from an economic and social point of view. With the help of a regression analysis that is intended at clarifying how rice price changes, and using data from various sources such as the FAO (population), the US Department of Agriculture (USDA for production quantity, harvested area, yield, ending stock and import export), the World Bank (GDP), Bloomberg (future markets), the EIA (Energy Information Administration) (biofuel production and consumption) and Index Mundi (prices of barley, corn, rice, wheat), the paper analyses the forces governing the trends in rice consumption and production. This paper concludes with a number of issues to be borne in mind when

\footnotetext{
1 In our data analysis we selected Thai white rice ' $5 \%$ Broken', which is well known in international markets.
} 
interpreting the results on the volatility of rice prices (according to the regression analysis results), the expected policy impact and distortions, and, finally, the "relatively" new strategies: a move from "food security" to "self-sufficient food security" at the level of each country, as once laid down in the goals of the Common Agricultural Policy in Europe (CAP).

\section{The rice market}

The 2008 world rice crisis, although quite coincident with the general food crisis, has to be analysed in a separate way. In fact, the two crises are coincident but the price formation process for rice has several dimensions that distinguish it from other cereal staples such as corn, wheat and barley.

Rice prices have been fairly constant over time, with a small increase (mid 2003) and sudden increases from the summer of 2007 in parallel with other cereals markets (Graph 1). These huge price increases have occurred in spite of substantial productivity gains in the rice market over the same time (Graph 4).

\section{Graph 1 - Selected cereal prices, US Dollars per Ton (1985-2009)}

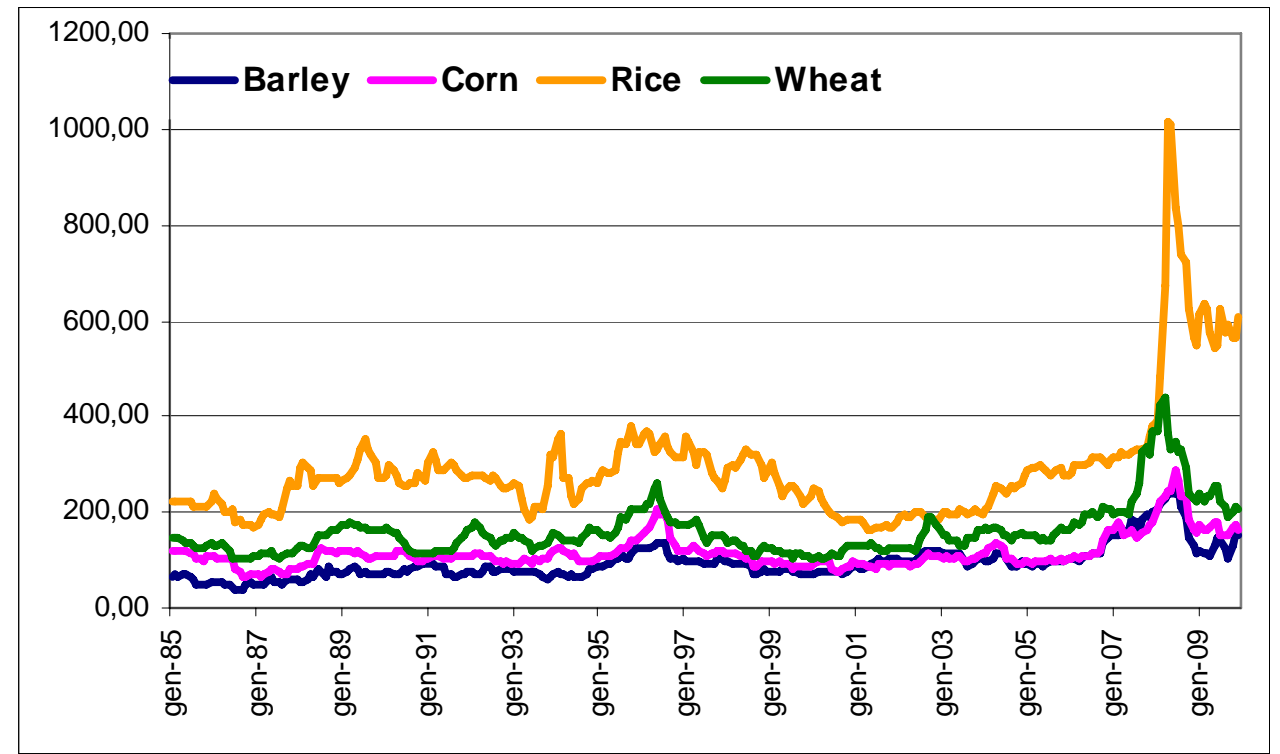

Source: INDEX MUNDI http:/ / www.indexmundi.com/commodities / 
Supply in the rice sector as well as in the agricultural sector is characterised by the biological nature of the production process (rice production is highly connected to climate risks such as monsoons in Asia), by the time lag between production (it is possible to obtain from one to four harvests per year) and consumption and by the law of diminishing returns (because of limited land).

The supply determinants are: cost of productions (energy and fertilisers, even if in some environment fertiliser are not utilised, but yields are low), profitability of alternative products (rice is an arable culture so many alternative cultures can substitute for it, if more convenient), existing levels of stocks, public policy (public intervention is very high in the rice sector). Since farmers are price takers, the production decisions are based on expected prices (usually referring to the price existing at this moment). However, the factors that affect the market price of rice are complex and widely debated and analysed in terms of their impact on poorer consumers and farmers. Some authors conclude that the most important factor of the rapid recent rise in food prices and, as a consequence, in rice prices, is the large increase in biofuel production (Mitchell, 2008; Kutas et al, 2007; IFRI, 2008). Others identify speculation as a source of increasing agricultural commodity prices in 2007-2008 (Robles et al 2009; Timmer, 2009; Pace et al, 2008). Although the relative importance of the different explanatory variables vary across studies, these analyses tend to agree with the broad conclusion that behind the rapid increase (and then decrease) in food prices, there are several factors at play.

Rice is the third largest produced cereal in the world after corn and wheat (Graph 2). Its production is strongly concentrated in Western and Eastern Asia, representing more than 90 per cent of the world total ${ }^{2}$. More than 2 thousand varieties of rice are cultivated in the world (Khush and

\footnotetext{
${ }^{2}$ Italy is the main producer in the European Union.
} 
Toenniessen, 1991), implying that the market is characterised by a high degree of product differentiation.

\section{Graph 2 - Cereal production trends, 1,000 ton (1985-2009)}

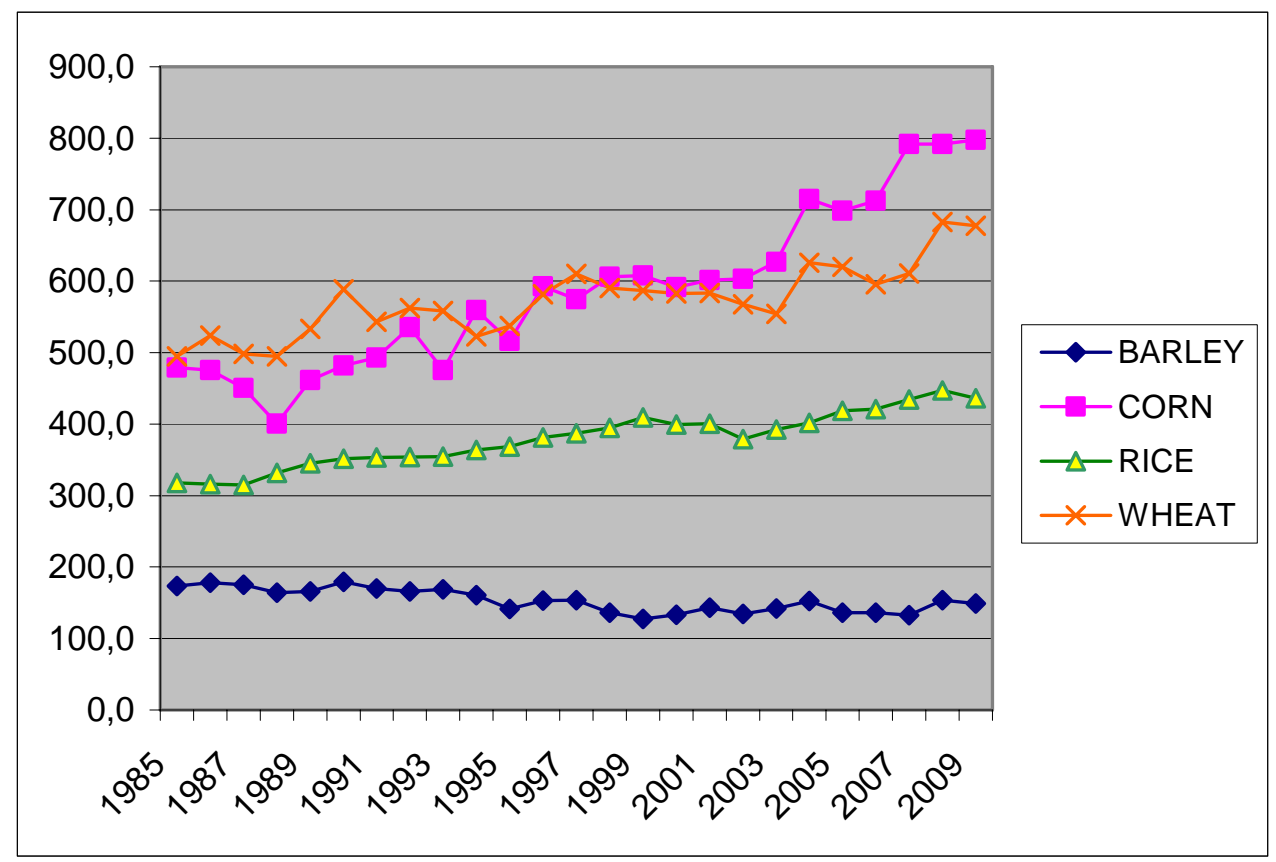

Source: USDA, Washington.

Table 1 - Rice production in Asia: main producing countries (1,000 ton)

\begin{tabular}{|c|c|c|c|c|c|c|c|c|c|c|c|c|}
\hline & 1985 & $\begin{array}{r}\% \text { on } \\
\text { World } \\
\end{array}$ & 1990 & $\begin{array}{r}\% \text { on } \\
\text { World } \\
\end{array}$ & 1995 & $\begin{array}{r}\% \text { on } \\
\text { World } \\
\end{array}$ & 2000 & $\begin{array}{r}\% \text { on } \\
\text { World } \\
\end{array}$ & 2005 & $\begin{array}{r}\% \text { on } \\
\text { World } \\
\end{array}$ & 2008 & $\begin{array}{r}\% \text { on } \\
\text { World } \\
\end{array}$ \\
\hline Bangladesh & 22,556 & $4 . .8$ & 26,778 & 5.2 & 26,399 & 4.8 & 37,628 & 6.3 & 39,796 & 6.3 & 46,905 & 6.8 \\
\hline China & 171,319 & 36.6 & 191,615 & 37.0 & 187,298 & 34.2 & 189,814 & 31.7 & 182,055 & 28.7 & 193,354 & 28.2 \\
\hline India & 95,818 & 20.5 & 111,517 & 21.5 & 115,440 & 21.1 & 127,465 & 21.3 & 137,690 & 21.7 & 148,260 & 21.6 \\
\hline Indonesia & 39,033 & 8.3 & 45,179 & 8.7 & 49,744 & 9.1 & 51,898 & 8.7 & 54,151 & 8.5 & 60,251 & 8.8 \\
\hline World & 468,165 & 100,0 & 518,556 & 100.0 & 547,430 & 100.0 & 599,355 & 100.0 & 634,507 & 100.0 & 685,013 & 100.0 \\
\hline
\end{tabular}

Source: FAOstat, Rome.

As can be seen in table 1 , China and India are two major rice producers in Asia (and in the world) with a combined production reaching more than 341 billion tons (roughly 50 per cent of the total world production) in 2008. The four main world producers are located in Asia because rice production is well-suited to countries and regions with low labour costs and high rainfall as it is labour-intensive to cultivate and it requires ample water.

During the period 1985-2009, the harvested area increased from 144.7 to 152.5 thousands ha and productivity rose from 3.23 to 4.27 tons $/$ h. At the 
time of writing, no large scale production of genetically modified rice is taking place and technology studies focus on processes able at economising water, hypoallergenic products, and vitamin A rice (kwon as Golden Rice).

\section{Graph 3 - Productivity trends, tons/ha (1985-2009)}

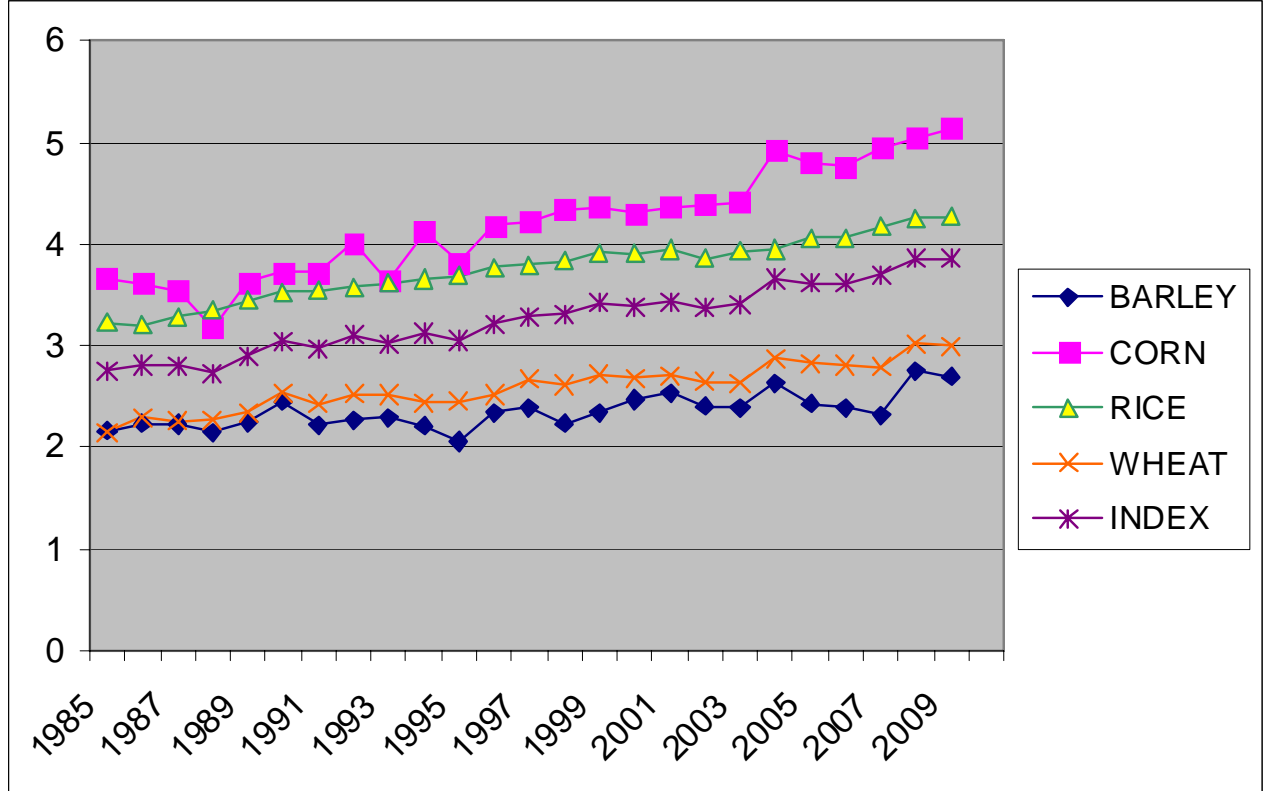

Source: USDA, Washington.

Even if the productivity curve as well as the production curve are constantly increasing, production and productivity growth rates have not been homogeneous in our selected country group (Graph 3 and Graph 4). Over the 1985-2009 period, production surged by 108 per cent in Bangladesh (Table 2), while in China it increased only by 12 per cent; in both India and Indonesia the rise is equal to 54 per cent. Referring to productivity, the highest value is observed in China (the main consumer country), the lowest in Thailand (the main exporting country). Bangladesh, the main importing country, occupies an in-between position. Large margins to improve rice productivity therefore exist. 
Graph 4 - Productivity of the main rice producers, tons/ha (1985-2008)

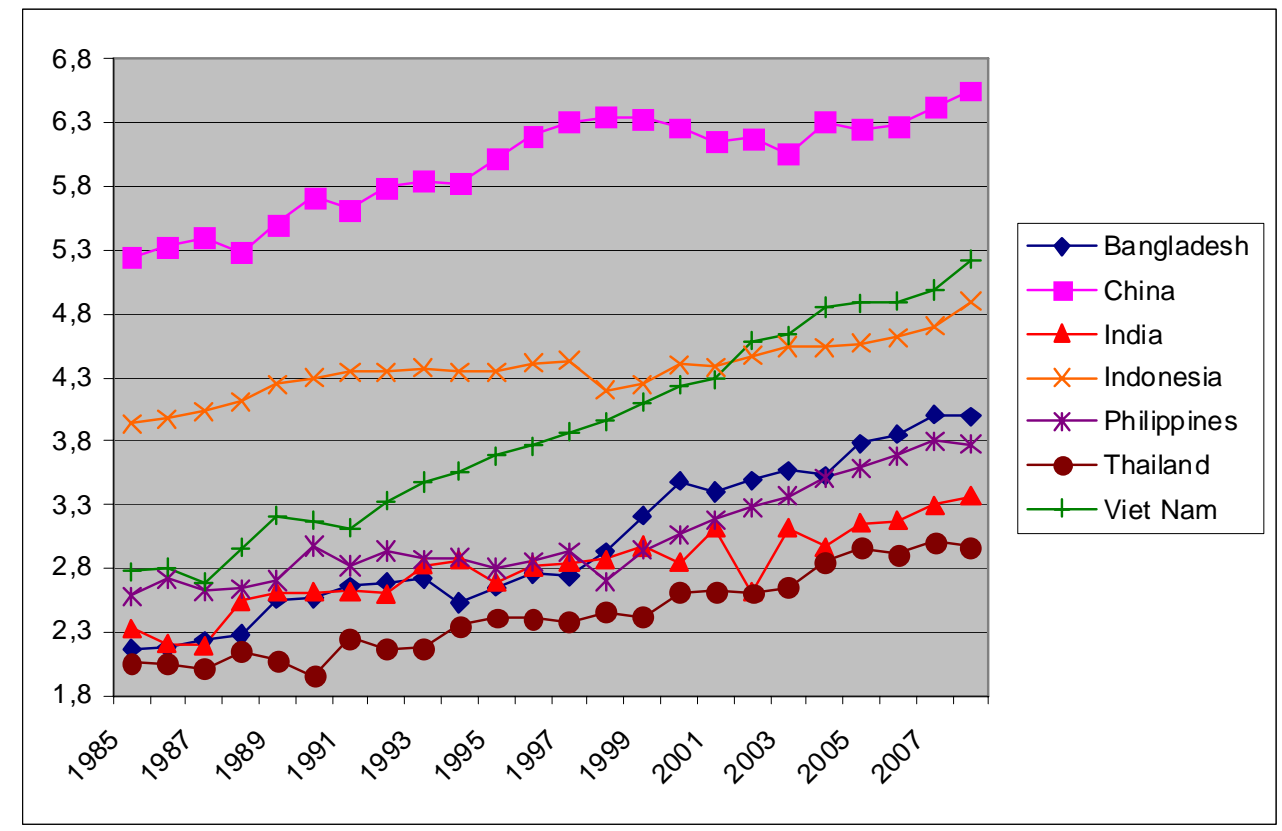

Source: elaboration on FAOstat data, Rome.

Consumption trends are similar to those of production (306.8 in thousands ton 1985 versus 434 in 2009) and, in the meantime, major rice producing countries are the larger rice consumers. Table 2 depicts the main consuming countries in Asia in volume terms over the years. If production increased by 46 per cent, consumption shows a percentage rise equal to 34 . From an industry linkages view point, the major rice users are: food and processing industry (pasta, bread, beer, liquor) and, in a smaller quantity, the pharmaceutical industry.

With regard to population, more than half of the world's population depends on rice as a staple food. More specifically, rice is a major food staple (small price and income substitution effects) and a mainstay for the rural population and their food security. It is mainly cultivated by small farmers in little holdings. Rice is also a salary commodity for workers in the cash crop or non-agricultural sectors. This dilemma of low prices for poor consumers and high prices for poor farmers has inspired conflicting policy objectives, with policy-makers intervening to save farmers when prices drop, or to defend consumer purchasing power when there are 
sudden price increases. In this market, culture, taste and preferences play a crucial role.

Although rice is today marginally traded on international markets, when compared with wheat and corn, it has been subject to protectionist trading practices for quite some time.

Table 2 Rice consumption in Asia: main countries $(1,000$ ton)

\begin{tabular}{|c|c|c|c|c|c|c|c|c|c|c|c|c|}
\hline & 1985 & $\begin{array}{r}\% \text { on } \\
\text { world } \\
\end{array}$ & 1990 & $\begin{array}{r}\% \text { on } \\
\text { world } \\
\end{array}$ & 1995 & $\begin{array}{r}\% \text { on } \\
\text { world }\end{array}$ & 2000 & $\begin{array}{r}\% \text { on } \\
\text { world } \\
\end{array}$ & 2005 & $\begin{array}{r}\% \text { on } \\
\text { world } \\
\end{array}$ & 2007 & $\begin{array}{r}\% \text { on } \\
\text { world }\end{array}$ \\
\hline Bangladesh & 20,037 & 5.2 & 25,639 & 6.0 & 27,535 & 6.1 & 32,239 & 6.6 & 35,817 & 7.0 & 37,776 & 7.2 \\
\hline China & 138,943 & 35.8 & 145,276 & 33.9 & 145,172 & 32.1 & 152,971 & 31.4 & 153,034 & 29.8 & 153,884 & 29.4 \\
\hline India & 83,022 & 21.4 & 101,816 & 23.7 & 107,760 & 24.0 & 113,472 & 23.3 & 120,944 & 23.6 & 123,841 & 23.7 \\
\hline Indonesia & 34,238 & 8.8 & 35,154 & 8.2 & 38,135 & 8.4 & 40,580 & 8.0 & 42,117 & 8.2 & 42,198 & 8.1 \\
\hline World & 388,562 & 100.0 & 428,868 & 100.0 & 451,821 & 100.0 & 487,528 & 100.0 & 512,776 & 100.0 & 522,595 & 100.0 \\
\hline
\end{tabular}

Source: FAOstat, Rome

With regard to trade, it is preferentially an Intra-Asian trade, and it is very marginal in terms of volume and value. Three Asian countries (China, Bangladesh and the Philippines) are among the top four rice importing nations in the world, whereas another three Asian countries (China, Thailand and India) are among the top four rice world exporters (Tables 3 and 4 respectively). In particular, the formidable increase of rice exports from both India and Viet Nam since the mid 1980s should be noted. Thailand dominated and still dominates world rice trade, despite its diminishing weight over the analysed period, contributing about 27 per cent of rice exports in 2007.. In 2007, world rice exports and imports were equal to 4 and 3 per cent of rice world production respectively, whereas this was only 2 per cent in 1985 . Undoubtedly this is a significant improvement but because of the small quantities traded it is still subjected to large price moves in the international markets. Yet, trade has for a long time been confined to the public domain, but now, with the relatively new rules in the WTO private exporters are growing. 
Table 3 - Top three rice importers (in 1,000 ton)

\begin{tabular}{|l|r|r|r|r|r|r|r|r|r|r|r|r|}
\hline & $\mathbf{1 9 8 5}$ & $\begin{array}{r}\text { \% on } \\
\text { world }\end{array}$ & $\mathbf{1 9 9 0}$ & $\begin{array}{r}\text { \% on } \\
\text { world }\end{array}$ & $\mathbf{1 9 9 5}$ & $\begin{array}{r}\text { \% on } \\
\text { world }\end{array}$ & $\mathbf{2 0 0 0}$ & $\begin{array}{r}\text { \% on } \\
\text { world }\end{array}$ & $\mathbf{2 0 0 5}$ & $\begin{array}{r}\text { \% on } \\
\text { world }\end{array}$ & $\begin{array}{r}\mathbf{2 0 0 7} \\
\text { world }\end{array}$ \\
\hline Bangladesh & 677 & 7.0 & 380 & 3.9 & 501 & 3.4 & 452 & 2.9 & 618 & 3.4 & 572 & 2.6 \\
\hline China & 213 & 2.2 & 58 & 0.6 & 1,613 & 10.9 & 244 & 1.6 & 533 & 2.9 & 500 & 2.3 \\
\hline Philippines & 538 & 5.6 & 593 & 6.1 & 263 & 1.8 & 642 & 4.1 & 1,100 & 6.0 & 1,900 & 8.8 \\
\hline World & $\mathbf{9 , 6 6 2}$ & $\mathbf{1 0 0 . 0}$ & $\mathbf{9 , 6 6 2}$ & $\mathbf{1 0 0 . 0}$ & $\mathbf{1 4 , 7 8 6}$ & $\mathbf{1 0 0 . 0}$ & $\mathbf{1 5 , 7 2 0}$ & $\mathbf{1 0 0 . 0}$ & $\mathbf{1 8 , 4 2 2}$ & $\mathbf{1 0 0 . 0}$ & $\mathbf{2 1 , 6 2 7}$ & $\mathbf{1 0 0 . 0}$ \\
\hline
\end{tabular}

Source: FAOstat, Rome.

Table 4 - Top 3 rice exporters (in 1,000 ton)

\begin{tabular}{|l|r|r|r|r|r|r|r|r|r|r|r|r|}
\hline & $\mathbf{1 9 8 5}$ & $\begin{array}{c}\text { \% on } \\
\text { world }\end{array}$ & $\mathbf{1 9 9 0}$ & $\begin{array}{c}\text { \% on } \\
\text { world }\end{array}$ & $\mathbf{1 9 9 5}$ & $\begin{array}{c}\text { \% on } \\
\text { world }\end{array}$ & $\mathbf{2 0 0 0}$ & $\begin{array}{r}\text { \% on } \\
\text { world }\end{array}$ & $\mathbf{2 0 0 5}$ & $\begin{array}{r}\text { \% on } \\
\text { world }\end{array}$ & $\mathbf{2 0 0 7}$ & $\begin{array}{r}\text { \% on } \\
\text { world }\end{array}$ \\
\hline Thailand & 3,898 & 39.2 & 3,558 & 34.1 & 5,533 & 27.8 & 5,282 & 27.0 & 6,044 & 24.9 & 7,408 & 27.0 \\
\hline India & 314 & 3.2 & 505 & 4.8 & 4,894 & 24.6 & 1,527 & 7.8 & 3,824 & 15.7 & 6,143 & 22.4 \\
\hline Viet Nam & 59 & 0.6 & 1,624 & 15.6 & 1,988 & 10.0 & 3,477 & 17.7 & 5,250 & 21.6 & 4,558 & 16.6 \\
\hline World & 9,934 & $\mathbf{1 0 0 . 0}$ & $\mathbf{1 0 , 4 2 5}$ & $\mathbf{1 0 0 . 0}$ & $\mathbf{1 9 , 8 8 7}$ & $\mathbf{1 0 0 . 0}$ & $\mathbf{1 9 , 5 9 2}$ & $\mathbf{1 0 0 . 0}$ & $\mathbf{2 4 , 3 0 5}$ & $\mathbf{1 0 0 . 0}$ & $\mathbf{2 7 , 4 3 4}$ & $\mathbf{1 0 0 . 0}$ \\
\hline
\end{tabular}

Source: FAOstat, Rome.

\section{Policies adopted in Asia and in the EU}

Faced with high and rising world food prices in 2007 and 2008, many countries adopted policy measures designed to reduce the impact of price increases on their domestic populations (FAO, 2009; Slayton, 2009). These measures, involving different key commodity sectors, can be classified into four broad categories: trade, production, consumption and stock policies. Most of these policy measures were implemented for limited periods of time. To these different categories we now turn, focusing first on the case of Asian countries.

\subsection{Trade-related measures}

On the export side, policies include export taxes and/or subsidies, and export bans and other quantitative restrictions. They have usually been applied by net exporting countries to enhance supply on their domestic market ${ }^{3}$. Examples of recent export policies in the rice market encompass the ban by India, - the world's third-largest rice exporter-, of exports of non-basmati rice, and the restriction of basmati rice supplies. China

\footnotetext{
3 An export subsidy reduces the price paid by foreign importers, which implies that domestic consumers pay more than foreign consumers. This is in contrast to taxes, bans and quotas, which involve a very high level of distortion, that tend to reduce prices in the domestic market. However, by reducing the gains for producers, they limit their longerterm supply response. Moreover, by curtailing exports, they tend to increase prices on international markets.
} 
eliminated rebates on value added taxes on rice exports (and on wheat, corn and soybeans) and imposed an export tax on a series of grains and products. Bangladesh, Cambodia, Indonesia and Viet Nam all banned exports of rice.

On the import side, the elimination or reduction of import duties and taxes on food commodities is one of the most commonly applied policy measures, and it is typically adopted by net importing countries. This measure has a strong impact on poorer people, because of their commodity consumption patterns. Thus, the reduction in taxes is progressive relative to income as poorer people tend to spend a larger share of their income on food. A number of countries (including the EU) reduced or eliminated food tariffs or taxes.

\subsection{Production policies}

A number of producer support measures were introduced such as increasing domestic prices (output price support), input subsidies, and an easing of cropland set-aside requirements aimed at promoting an expansion in production. These policies are generally expensive and the impact on domestic consumer prices is limited in the context of open markets but they are more substantial if linkages to international markets are weak ${ }^{4}$. The easing of set-aside requirements, which may otherwise constrain the production response to higher prices, is most effective at increasing production and may effectively reduce domestic prices in a closed-market situation ${ }^{5}$. Countries that increased input subsidies include Bangladesh, China, and Indonesia.

In order to increase production, Indonesia launched a rice intensification programme involving the State Board of Logistics (Bulog), private

\footnotetext{
${ }^{4}$ If not well administered, input subsidies may also lead to an increase in input prices as demand for inputs increases, thus benefiting input suppliers more than agricultural producers.

${ }^{5}$ In the case of major exporters, such as the EU, it may also have a significant dampening effect on international prices.
} 
companies, banks and groups of farmers. The fertilizer subsidy was also increased by 240 percent (FAO, 2009).

China increased its floor price for rice (and wheat) with the aim to expand production in order to reduce import dependence. India increased the minimum support for common paddy rice by as much as 37 percent between 2006/07 and 2008/09 (FAO, 2009).

China expanded non-price government support, including direct payments, seed subsidies, subsidies for farm machinery, and subsidies for fuels used on farms as well as fertilizers to farmers in 2008 (Fang, 2009). Moreover, the Government imposed chemical fertilizer export taxes several times in 2008 in order to control exports and to satisfy domestic demand from farmers.

\subsection{Consumption policies}

Policies to support consumers and vulnerable groups include the following: direct consumer subsidies; tax reductions; distribution from public stocks; price subsidies; public-sector salary increases; and social safety- net programmes.

\section{Direct consumer subsidies and social safety-net programmes}

Self-targeting food-for-work programmes have been put in place by countries such as Bangladesh, Cambodia and India, while Bangladesh and Cambodia have distributed emergency food aid. School feeding programmes have been implemented in China. Countries such as Indonesia, Mongolia, and the Philippines have sold food at subsidized prices to targeted groups of households.

\subsection{Stock policies}

A buffer stock scheme is an attempt at stabilising prices in an entire economy or, more commonly, an individual (commodity) market. Specifically, commodities are bought and stored when there is a surplus, stored, and then sold from these stores, when there are shortages. In a 
context of closed domestic markets, depending on buying and selling behaviour, stock policies may stabilize or destabilize domestic prices.

Bangladesh, China, India, Indonesia, and Pakistan all released food from public stocks to lessen price increases and offered targeted and untargeted subsidies for staple food.

The Food Corporation of India made record purchases of rice (and wheat) in 2008, allowing it to release sufficient stocks into the domestic market to stabilize prices. The Government of the Philippines, the world's largest rice importer, increased its imports from 1,100 thousands tons in 2005 to 1,900 thousands tons in 2007 (FAO, 2009).

To further protect the market, Japan resisted rice imports until the Uruguay Round of global trade talks in 1995, when it agreed to start buying some 682,000 tons of foreign rice a year, mostly from the U.S. But the Japanese government, which controls rice sales, does not sell the imported rice on the market. This is because Japan's rice production exceeds Japan's rice consumption and because of, the fact that, culturally speaking, 'agriculture is rice' in Japan. Yet, fearing that cheap foreign rice would further erode domestic prices (usually about five times the international price), it has been storing the foreign rice for years, amassing a huge stockpile. Some of the reserves have been fed to livestock, fermented to make miso paste, and even given away to North Korea as aid. Still, at the end of 2007, Japan had 2.29 million tons of rice in storage -- 1.52 million tons of imported rice and 770 thousands tons of domestic rice, which the government says is for of emergency use (FAO, 2009).

Table 5 summarizes the main support measures adopted in 2007 and 2008 by the different Asian countries under review. 
Table 5 - Support measures adopted in Asia (2007 and 2008)

Main Producing Countries

\begin{tabular}{|c|c|c|c|c|}
\hline Countries & $\begin{array}{l}\text { Trade } \\
\text { measure }\end{array}$ & $\begin{array}{l}\text { Production } \\
\text { policies }\end{array}$ & $\begin{array}{l}\text { Consumption } \\
\text { policies }\end{array}$ & $\begin{array}{l}\text { Buffer } \\
\text { stocks }\end{array}$ \\
\hline China & $\begin{array}{l}\text { Export } \\
\text { measures }\end{array}$ & $\begin{array}{l}\text { Increasing } \\
\text { floor price } \\
\text { and input } \\
\text { subsides }\end{array}$ & $\begin{array}{l}\text { School feeding } \\
\text { programmes }\end{array}$ & \\
\hline India & $\begin{array}{l}\text { Banned } \\
\text { exports }\end{array}$ & $\begin{array}{l}\text { Increasing } \\
\text { minimum } \\
\text { support }\end{array}$ & & $\begin{array}{l}\text { Stock of } \\
\text { rice }\end{array}$ \\
\hline Indonesia & $\begin{array}{l}\text { Banned } \\
\text { exports }\end{array}$ & $\begin{array}{l}\text { Input } \\
\text { subsides }\end{array}$ & $\begin{array}{ll}\text { Food } & \text { at } \\
\text { subsidised } & \\
\text { prices } & \text { to } \\
\text { vulnerable } & \\
\text { groups } & \\
\end{array}$ & \\
\hline Bangladesh & Export tax & & $\begin{array}{l}\text { Emergency } \\
\text { food aid }\end{array}$ & \\
\hline
\end{tabular}

\section{Main consumption countries}

\begin{tabular}{|c|c|c|c|c|}
\hline Countries & $\begin{array}{l}\text { Trade } \\
\text { measure }\end{array}$ & $\begin{array}{l}\text { Production } \\
\text { policies }\end{array}$ & $\begin{array}{l}\text { Consumption } \\
\text { policies }\end{array}$ & $\begin{array}{l}\text { Buffer } \\
\text { stocks }\end{array}$ \\
\hline China & $\begin{array}{l}\text { Export } \\
\text { measures }\end{array}$ & $\begin{array}{l}\text { Increasing } \\
\text { floor price } \\
\text { and input } \\
\text { subsides }\end{array}$ & $\begin{array}{l}\text { School feeding } \\
\text { programmes }\end{array}$ & \\
\hline India & $\begin{array}{l}\text { Banned } \\
\text { exports }\end{array}$ & $\begin{array}{l}\text { Increasing } \\
\text { minimum } \\
\text { support }\end{array}$ & & $\begin{array}{l}\text { Stock of } \\
\text { rice }\end{array}$ \\
\hline Indonesia & $\begin{array}{l}\text { Banned } \\
\text { exports }\end{array}$ & $\begin{array}{l}\text { Input } \\
\text { subsides }\end{array}$ & $\begin{array}{ll}\text { Food } & \text { at } \\
\text { subsidised } & \\
\text { prices } & \text { to } \\
\text { vulnerable } & \\
\text { groups } & \end{array}$ & \\
\hline Bangladesh & Export tax & & $\begin{array}{l}\text { Emergency } \\
\text { food aid }\end{array}$ & \\
\hline
\end{tabular}

\section{Main importing countries}

\begin{tabular}{|l|l|l|l|l|}
\hline Countries & $\begin{array}{l}\text { Trade } \\
\text { measure }\end{array}$ & $\begin{array}{l}\text { Production } \\
\text { policies }\end{array}$ & $\begin{array}{l}\text { Consumption } \\
\text { policies }\end{array}$ & $\begin{array}{l}\text { Buffer } \\
\text { stocks }\end{array}$ \\
\hline Bangladesh & Export tax & $\begin{array}{l}\text { Emergency } \\
\text { food aid }\end{array}$ & $\begin{array}{l}\text { Food } \\
\text { subsidised at } \\
\text { prices } \\
\text { vulnerable } \\
\text { groups }\end{array}$ & $\begin{array}{l}\text { Stock of } \\
\text { rice } \\
\text { (import) }\end{array}$ \\
\hline Philippines & & & \\
\hline
\end{tabular}

With regard to trade related measures, rice markets, which are relatively

'thin' compared with global production and consumption levels, were 
clearly destabilized by the policies implemented to address high food prices, with significantly higher international prices in 2007 and 2008. The most distorting policies in the case of rice were border policies implemented in 2007 and 2008. Consumption policies affected only the welfare of vulnerable households groups.

\subsection{The EU rice regime}

Although rice does not have the same strategic impact in the EU when compared with Asian countries, the rice market is the object of a common organisation at EU level. The Council regulation (EU) n. 1785/2003 is the legislative text of the EU common organisation of the market in rice (EC, 2003) that reformed the EU rice market. The starting point for such intervention is the awareness of the unbalance prevailing on the European rice market. As shown in Table 6, EU consumption has by far outstripped EU production. over the years.

Table 6 - Rice consumption and production in the European Union 27 $(1,000$ ton $))$

\begin{tabular}{|l|r|r|r|r|r|r|}
\hline & $\mathbf{1 9 8 5}$ & $\mathbf{1 9 9 0}$ & $\mathbf{1 9 9 5}$ & $\mathbf{2 0 0 0}$ & $\mathbf{2 0 0 5}$ & $\mathbf{2 0 0 7}$ \\
\hline Consumption & 2,410 & 2,493 & 2,802 & 3,530 & 3,717 & 3,802 \\
\hline Production & 2,126 & 2,369 & 2,151 & 2,487 & 2,664 & 2,618 \\
\hline
\end{tabular}

Source: FAOstat, Rome.

According to the 2003 regulation, the decision was intended at reducing the intervention price so as to balance demand and supply and to compensate farmers for the lower incomes, mainly those located in traditional production areas with income payment per farm and a crop specific aid. The quantities bought in by the intervention agencies were fixed at 75 thousands tonnes per year. As far as external frontiers are concerned, import or export license for imports into the Community ${ }^{6}$, or exports therefrom were set up. Export refunds (based on the difference between

\footnotetext{
${ }^{6}$ The licenses may be issued by the Member States to any applicant.
} 
prices within the European Union and those prevailing on the world market) have been subjected to limits in terms of value and quantity.

A quota free access for rice imports from LDCs since September 2009 was planned. Even if only few LDCs are net exporters of rice, the drastic cut in the intervention price could bring the EU border regime close to a zero duty scenario. Specific agreements with some Asian region (India, Pakistan, Thailand) were foreseen (EC, 2006).

\section{Pricing in the rice market}

In order to analyze all the variables that may have some power in explaining price changes in the rice market, a regression analysis is used by combining high frequency data spanning over the period January 1999 to December 2009 .

In our regression analysis (OLS, Ordinary Least Squares method), the dependent variable is the logarithmic of rice price ${ }^{7}$. Since the increase in the price of rice may have different implications in the short-run and in the long-run ${ }^{8}$ at both the farm and macroeconomic levels (economic and social), we need to distinguish between them. Our analysis will nevertheless focus on the results in the long-run only?

In the equation, we insert a dummy variable (DUM) to capture the strong intervention of policy makers at the end of 2007. This allows us to distinguish between two periods: the first from January 1999 to December 2007, the second encompasses 2008 and 2009. The dummy variable assumes the value 0 in the first period and 1 in the second period.

7 Although not every data point is available for the entire period of time, E-Views automatically adjusts the sample, considering only the period of time for which all time series are simultaneously available.

8The short run regression utilises the first difference of the variables. For this reason, an observation is missing (the first) and the sample is adjusted without the missing data. A Newey-West HAC Standard Errors \& Covariance (lag truncation=4) estimator allows to obtain consistent estimates of standard errors with respect the autocorrelation and heteroskedastic effects.

9 The long-run equation 7 is not a spurious regression. All the variables that enter in the equation are integrated of order one. Nevertheless, the ADF test on the residuals of this equation refuses the presence of unit roots, so that all the variables in the model are cointegrated, that is, the regression coefficients are meaningful and can be interpreted as long-run coefficients. 
The variables with potential explanatory power are: population, rice production, rice exports (as a percentage of total production), the dollareuro exchange rate, ending stocks, the GDP of two groups of countries, namely developing countries - where rice is seen as having a strategic importance -, and developed countries where this is not the case, and biofuels.

The results of our regression analysis show that futures markets ${ }^{10}$, biofuels, population, ending stocks and other cereals prices are not significant independent variables in the long run (table 7). The variables that were statistically insignificant have been eliminated from the analysis.

This leaves the following variables for the first period, by order of significance: developing country GDP with a positive relationship, developed country GDP (GDP_DEV) with a negative relationship and the incidence of export rice on total rice production (RICE_EXPRATE); in the second period, the following variables are statistically significant: the dollar-euro exchange rate (EXRATE) and the developing countries' GDP (GDP_LDC), both with a positive relationship.

\footnotetext{
10 The first futures exchange market was the Dōjima Rice Exchange in Japan in the $1730 \mathrm{~s}$, to meet the needs of samurai who, being paid in rice, could convert their rice in coins.
} 


\section{Table 7 Regression analysis results}

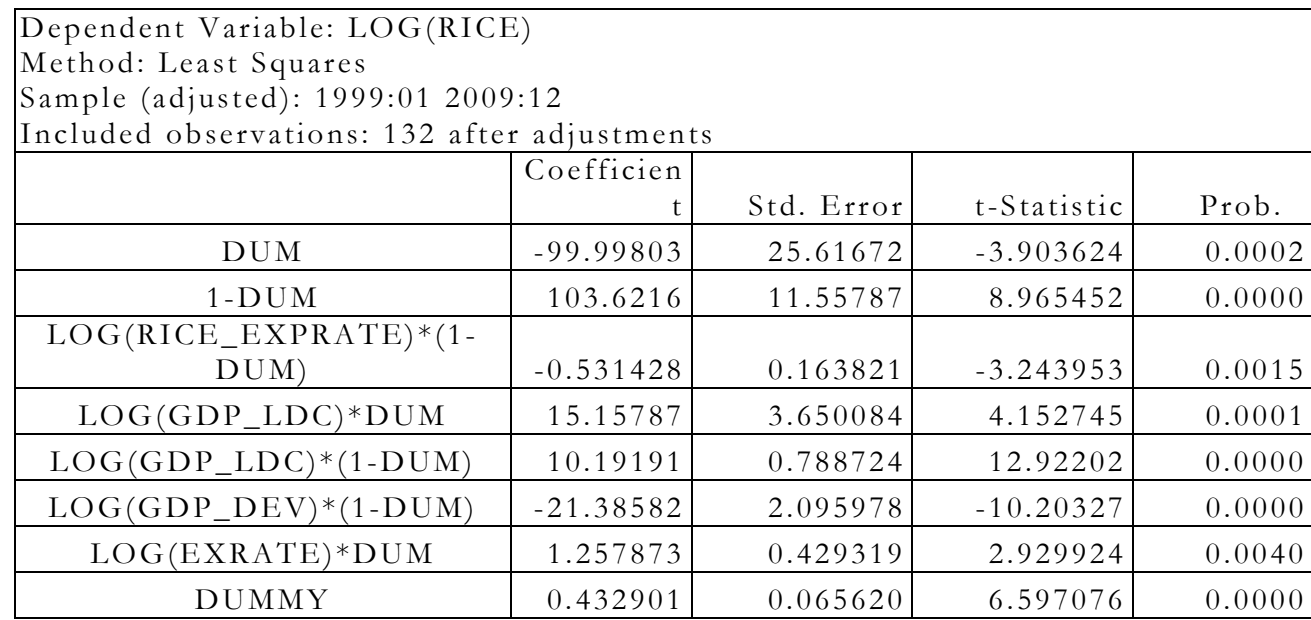

Dependent Variable: LOG(RICE)

Method: Least Squares

Sample (adjusted): 1999:01 2009:12

Included observations: 132 after

adjustments

\begin{tabular}{|c|c|}
\hline & Coefficien \\
\hline R-squared & 0.957299 \\
\hline Adjusted R-squared & 0.954889 \\
\hline S.E. of regression & 0.093197 \\
\hline Sum squared resid & 1.077025 \\
\hline Log likelihood & 130.0677 \\
\hline Durbin-Watson stat & 0.534119 \\
\hline
\end{tabular}

Remark: The dummy (1-DUM) refers to the first period and the dummy DUM to the second. Thus, for example, the coefficient of the dummy variables (1-DUM) is the intercept of the first period; the coefficient of DUM is the intercept of the second period)

The results of the adjusted $\mathrm{R}$-squared show that more than 95 per cent of the variation of rice prices is explained by the regression analysis and that this model has therefore a rather large explicative power.

Graph 5 shows the structural break in the long-run rice price curve, with strong price increases (right-hand scale in log form) from 2007 leading to strong policies from that time. 


\section{Graph 5. The long-run rice price curve}

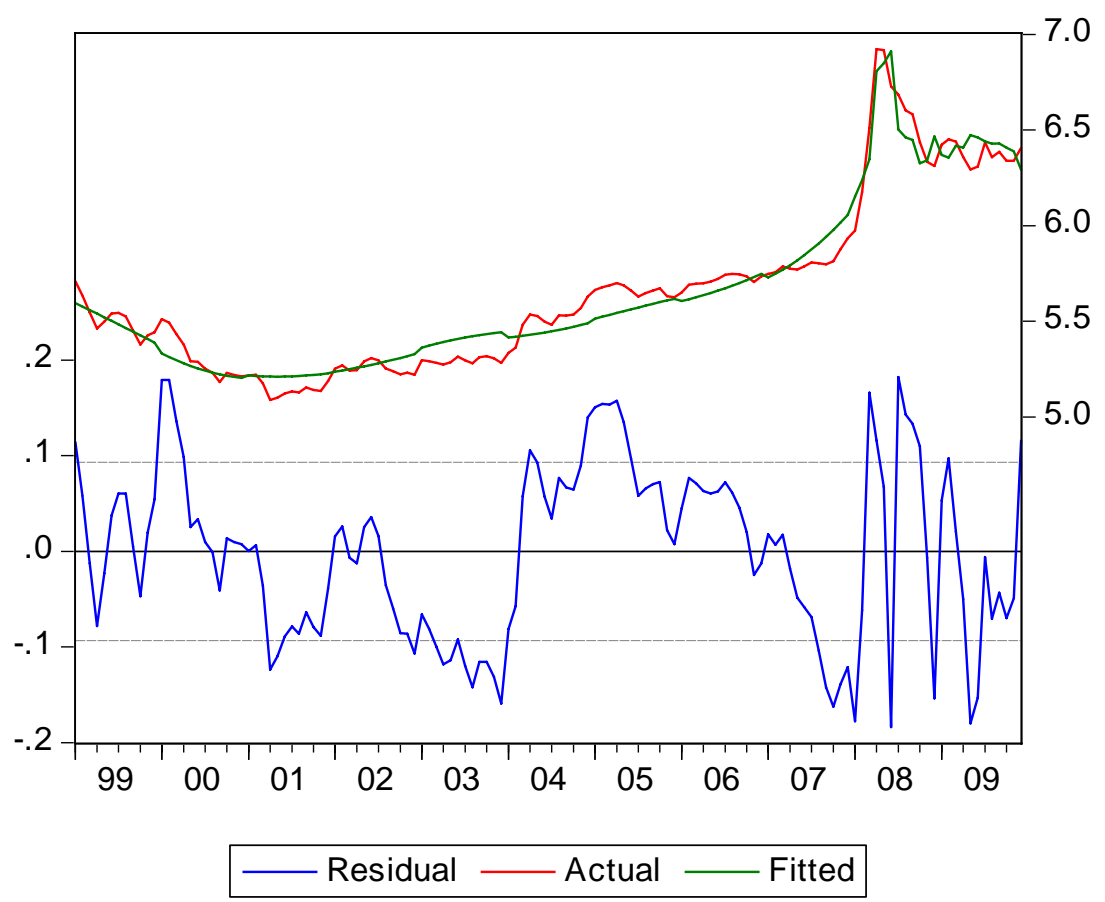

The sign of the coefficients of developed countries' GDP (GDP_DEV, in the first period, is negative, implying an inverse relationship existing between these variables and rice price changes (an expected result in the case of the relationship between price and exports/production). The inverse relationship between the GDP of developed countries and the price of rice translates the inferior status and non strategic role of rice in the basket of a typical household from these countries. This is in sharp contrast with the situation in developing countries where the relationship between price and GDP is positive and the most statistically significant of all (for both the first and second periods). This result confirms the strategic importance of rice in these countries and it justifies the implementation of policies that protect the end consumer from erratic price increases. The US dollar - euro exchange rate also has a positive and significant relationship with price, in the second period, reflecting the relatively weakening dollar over the period under analysis. Finally, the 
negative relationship between rice price and exports/production, in the second period, is a signal of more international close markets, as expected.

\section{Concluding remarks}

The 2008 food crisis was a prelude to the current economic crisis, and the rice sector was not sheltered from these world imbalances. The rise of food prices was without precedent; it was highest in the cereals sector and it increased strongly the number of undernourished people. In the case of corn and wheat, a number of factors are established as being responsible for price increases, in different proportions and weights, such as speculation and biofuel production.

The rice market is the most protected cereals market in the world because of its relevance as a staple food and as an income resource for poor farmers in developing countries. This leads to a dilemma in terms of public policies adopted in the past and in the last period under review in this article, i.e. 1999 to 2009.

Our analysis underlines that improvements in rice productivity are possible, but, also, that production still surpassed consumption at the world level. Nevertheless, with production being concentrated in Asia, the situation is made complicated by the fact that some countries are chronically importers, while others are exporters. The common factor is the high consumption per capita and its high emotional, cultural and historical connections.

The main producers' countries show different levels of productivity. The highest value is observed in China, and the lowest in Thailand, the latter being also the most important exporter country. However, the increase of productivity could pose some relevant environmental issues (due to limited resources of land and water).

Our regression analysis underlines that the main independent variables explaining rice price changes are developing countries' income, public 
policies, the US\$-euro exchange rate and the share of trade in total production.

Developing countries' GDP is the most statistically significant variable of all implying that rice is not only a staple food but a symbolic food item that is essential in the eyes of Asian people.

If we compare some selected public policies adopted in Asian countries with those of the EU, we can observe that the objective of the EU rice regime is ultimately to guarantee a sufficient income to farmers, without any particular attention being devoted either to consumers or to less developed countries. In the analysed Asian countries, the public instruments refer mainly to trade measures (export bans) often finalised with the aim of maintaining and protecting domestic prices, which are generally higher than those prevailing at world level. Vulnerable people have generally been protected with food help programmes.

The fear that rice can be produced cheaply in other parts of the world where better and sophisticated technologies or a cheaper work force could affect production costs, and that therefore foreign rice could be sold at a cheaper level, is the premise of all public interventions. Usually, protectionism can be looked as bringing advantages in the short run, whenever the successful implementation of policies can quickly lessen price volatility, but it is undoubtedly negative in the long run. Agricultural trade is still an important element of world trade, and revenues from agricultural protectionism play a significant role. This is confirmed also in our regression analysis were a negative relationship links rice prices and the incidence of exports on total production. 


\section{References}

European Council Regulation (EC) No. 1785/2003 of 29 September 2003 on the common organisation of the market in rice.

European Council Regulation (EC) No. 797/2006 of 22 May 2006 amending Regulation (EC) No. $1785 / 2003$ as regards the arrangements for importing rice.

FAO (2009) The state of agricultural commodity Market, Rome.

IFRI (2008) Biofuels and grain prices: Impacts and policy responses.

Khush G, Toenniessen G (1991) "Rice Biotechnology", Biotechnology in Agriculture No.6.

Kutas G, Lindberg C and Steenblik R (2007) Biofuels: At what cost? Government Support for Ethanol and Biodiesel in the European Union. A report for the International Institute for Sustainable Development, Geneva, Switzerland.

Mitchell D (2008) A note on rising food prices. Policy research working paper No. 4682. World Bank.

Pace N, Seal A, Costello A (2008) "Food commodity derivatives: a new cause of malnutrition?" The Lancet 371:1648-1650. doi:10.1016/S01406736(08)60707-2.

Robles M, Torero M, von Braun J(2009) When speculation matters. IFPRI Issue Brief 57 .

Slayton T (2009) Rice crisis forensics: how Asian governments carelessly set the world rice market on fire. Working paper No. 163. Center for global development.

Timmer PC (2009) Did speculation affect world rice prices? ESA working paper No. 09-07 FAO. 